\title{
ROLA KURATORA RODZINNEGO W PROCESIE KSZTAETOWANIA ASPIRACJI ŻYCIOWYCH PODOPIECZNEGO - STUDIUM TEORETYCZNE
}

\author{
WioletTa KajaK \\ wiolkaja@gmail.com
}

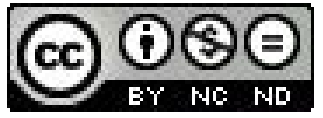

Ludzkie istnienie nieodzownie związane jest $\mathrm{z}$ formami procesualnymi. Są to reakcje przebiegające zarówno na poziomie biologicznym jak metabolizm; psychologicznym (np. kształtowanie tożsamości) oraz społecznym (np. socjalizacja). Egzystencja urasta zatem do formy dynamicznego systemu, permanentnie ulegającego modyfikacjom $w$ kierunku: progresu, regresu lub pozostawania w stanie przejściowym - pewnej stagnacji-zwanej plateau ${ }^{1}$. Jest to pozycja niezwykle znacząca z punktu widzenia rozwoju człowieka. Przygotowuje bowiem organizm do kolejnej zmiany. Określana jest jako czas porządkowania, integracji skutkującej koncentracją sił i absorpcją zasobów², których dalsza dystrybucja ukierunkowana zostanie na realizację określonego celu biologicznego, psychologicznego lub społecznego. Problem pojawia się w momencie zaburzenia homeostazy organizmu, czyli stanu równowagi procesów progresywnych i regresywnych, przeważając na jedną ze stron lub pozostając w przedłużającym się stanie stagnacji rozwojowej. Jeśli zatem zmniejszenie aktywności mięśni prowadzi do ich zaniku, zatem analogicznie, brak aktywności człowieka w określonym kierunku prowadzi do utraty jego kompetencji. Formy regresywne są naturalnym stanem $\mathrm{w}$ okresie przejrzewania organizmu - określanym według nomenklatury erikosonowskiej-starością? . Te zmiany, związane z wygaszaniem szeroko pojętej aktywności życiowej, pełnią określoną funkcję rozwojowa, związaną z tzw. „zmierzchem życia”. Ambiwalentną sytuację rozwojową obserwujemy w przypadku młodego organizmu, gdzie podstawową formą osiagania homeostazy są procesy progresywne. Zadaniem młodego człowieka jest stałe ukierunkowanie na pomnażanie zdrowia, rozumianego w koncepcjach salutogenetycznych jako potęgowanie zasobów wewnętrznych w postaci zyskiwania nowej wiedzy czy poszczególnych kompetencji.

Dlaczego zatem tak często spotykamy się sytuacją zatrzymania rozwoju człowieka? Analizując akta nadzoru nieletnich znajdujemy powtarzające się niemal w każdym przypadku schematy przerwania obowiązku szkolnego na etapie gimnazjum (bądź wcześniej), braku zainteresowań czy planów na przyszłość. Źródeł tego stanu możemy doszukiwać się, w zależności od przyjętych podstaw teoretycznych, w strukturze rodziny i szkoły, w stopniu realizacji ich funkcji, w kulturze czy cechach osobistych jednostki. Większość koncepcji sytuuje je w warunkach zewnętrznych-niezależnych od kontroli młodego człowieka. Zaburzenie zachowania (antagonizm destruktywny) $)^{5}$ jest więc naturalną reakcją jednostki na dysfunkcyjne warunki w jakich przyszło

A. Matlakiewicz, H. Solarczyk-Szwec, Dorośli uczą się inaczej, Toruń 2009, s. 16.

A. Brzezińska, Psychologia rozwoju człowieka, [w:] J. Strelau (red.), Psychologia, t. 1, Gdańsk 2000, s. 237-238.

3 Nt. nomenklatury oraz periodyzacji starości-późnej dorosłości por.: M. Straś-Romanowska, Późna dorostość. Wiek starzenia się, [w:] B. Harwas-Napierała, J. Trempała (red.), Psychologia rozwoju człowieka. Charakterystyka okresów życia, t. 2, Warszawa 2007, s. 264-265.

4 Przegląd teorii dotyczących mechanizmów kształtowania się zachowania w kontekście wyszczególnionych uwarunkowań zawiera pozycja: J. Petraitis, B. R. Flay, T. Q. Miller, Reviewing Theories of Adolescent Substance Use: Organizing Pieces in the Puzzle, "Psychological Bulletin” 1995, vol. 117 (1).

5 Według E. Wysockiej antagonizm destruktywny jest formą niedostosowania będącego wynikiem kumulacji niekorzystnych czynników rozwojowych; rodzajem tożsamości negatywnej; wadliwą integracją postaw i ról przejawiającą się w zewnętrznie manifestowanym dewiacyjnym zachowaniu, E. Wysocka, Diagnoza w resocjalizacji, Warszawa 2008, s. 107. 
się jej socjalizować. Jeśli usztywnione w dewiacyjnych schematach otoczenie jednostki stanowi granice resocjalizacji, należy oddziaływania naprawcze przekierować na osobę nieletniego-upatrując w jego ukrytym potencjale źródła indywidualnych zmian oraz motywować do rozwoju w celu przełamania dotychczasowych głęboko uwewnętrznionych standardów.

Jednym ze sposobów prewencji rozwoju zaburzeń zachowania, może być koncentracja oddziaływań na aspiracjach życiowych nieletniego, a narzędziem ich realizacji - kurator sądowy.

Za aspiracje, $\mathrm{w}$ ujęciu socjologicznym, możemy uznać zespół (ogół) pragnień oraz dążeń akceptowanych i definiowanych przez jednostkę jako ważne, jednocześnie przesądzających o jej osobistej przyszłości. Interpretowane są również jako dynamicznie zmieniające się (wzrastające i wygasające) dominujące potrzeby, zainteresowania jednostki lub grupy objęte silnym umotywowanym zamiarem realizacji poprzez odwoływanie się ich do hierarchii wartości (podstawowy komponent ludzkiej aktywności) $)^{6}$. A. Kłoskowska ujmuje je w kategorii uświadomionych oraz uznawanych za godne pożądania potrzeb, „odnoszących się do przedmiotów i wartości aktualnie nieposiadanych lub takich, które wymagają stałego odnawiania”. Autorka podkreśla ich elastyczna, stale zmieniająca się strukturę, którą J. Szczepański wiąże z rozwojem osobowości jednostki w toku zyskiwania doświadczenia życiowego.

Zważywszy na młody wiek podopiecznego, wg Ustawy o postępowaniu $w$ sprawach nieletnich środek opiekuńczo-wychowawczy w postaci nadzoru kuratora orzeka się wobec jednostki w wieku od 13 do 17 r.ż., która popełniła czyn karalny ${ }^{7}$, do 18 roku jeśli występuje zagrożenie demoralizacją, zaś w wyjątkowych sytuacjach podyktowanych dobrem dziecka stosuje się go aż do momentu uzyskania przez nie 21 lat'. Istnieje okoliczność, w której pośrednio nadzorem kuratorskim obejmowane jest dziecko w młodszym wieku. Jest to sytuacja ograniczenia władzy rodzicielskiej ${ }^{10}$. Przekazując częściowy obowiązek sprawowania pieczy nad małoletnim w ręce przedstawiciela wymiaru sprawiedliwości (wykształconego, doświadczonego człowieka o nieskazitelnym charakterze) ${ }^{11}$, umożliwia się jednostce kontakt z (być może pierwszym) prawidłowym wzorem postępowania czy przychylnym, stosującym pozytywne wzmocnienia nauczycielem umiejętności życiowych.

Choć w środowisku zawodowym sądowych kuratorów rodzinnych występują jednostki, które przyjmują kontrolno-represyjną postawę wychowawcza, pozostałą część stanowią ludzie poczuwający się do realizacji swoistej misji niesienia pomocy podopiecznemu ${ }^{12}$. Sformułowanie "pomoc", w tej sytuacji, będzie oznaczać wsparcie jednostki w rozwoju, czyli paralelną formę profilaktyki, a nie ograniczenie się do czynności opiekuńczych czy optymalizujących względem przyjętych społecznie norm. Kurator nie może utracić tożsamości pedagogicznej. Winny jest realizowania społecznej misji niesienia wsparcia i miłości w opiece czy korekcie dewiacyjnych postaw, a także nie-

6 P. Długosz, Aspiracje życiowe młodzieży pogranicza, Kraków 2010, s. 28.

Ustawa z dn. 26 października1982 r. o postępowaniu w sprawach nieletnich, art. 1,ust. 2.

Tamże, art. 1,ust. 1.

Tamże, art. 1,ust. 3.

10 Kodeks Rodzinny i Opiekuńczy z dn. 25 lutego 1964 r., art. 109, ust. 3.

11 Ustawa $z$ dn. 27 lipca 2011 r. o kuratorach sądowych określa wymagania jakie musi spełniać osoba mianowana na kuratora zawodowego art. 5, ust. 1 oraz społecznego art. 84, ust. 1.

12 Postawa kontrolno-represyjna opiera się o wywieranie nacisku, kontroli i wymuszenia podporządkowania podopiecznego w celu wywiązania się przez niego z narzuconych mu obowiązków; realizacja misji zawodowej w literaturze wiązana jest z modelem psychoterapeutycznym kurateli K. Sawickiej z 1985 r., u której podstaw sytuuje się procedurę case-work i social-work czy system oddziaływań na nieletniego C. Czapówa, gdzie kurator przyjmuje role inspiratora i koordynatora oddziaływań psychologicznych, społecznych, dydaktycznych, lekarskich jako autorytet. L. Pytka, Pedagogika resocjalizacyjna. Wybrane zagadnienia teoretyczne, diagnostyczne i metodyczne, Warszawa 2008, s. 271. 
ustannego kierowania się troską o dobro podopiecznego nawet kosztem własnych przekonań czy osobistych interesów. Ma aranżować najbliższe otoczenie podopiecznego w taki sposób, by sprzyjało realizacji jego zadań rozwojowych, przekształcać środowisko wychowawcze (rodzinne, szkolne) oraz rewidować negatywną opinię społeczna, ograniczającą proces resocjalizacji. Kurator musi zawsze wierzyć w wychowanka, koncentrować się na dobrych intencjach jego działania oraz poszukiwać zasobów, które stanowić będą punkt wyjścia planowanych oddziaływań reedukacyjnych. Ponadto winien odwoływać się do potrzeb, odczuć i pragnień młodocianego w taki sposób, by nie naruszyć ram orzeczenia sądowego oraz uwzględniać tendencje społeczne, zogniskowane w obrębie określonych ról. Profesjonalną praktykę winien oprzeć o własny, jednolity system pracy, który łączyć będzie aktywność animatora, protagonisty idei służebnej, towarzysza, przyjaciela i przewodnika ${ }^{13}$. Jak określiłby to jeden z najwybitniejszych współczesnych praktyków i teoretyków polskiej myśli resocjalizacyjnej- A. Szecówka, kurator winien być prawdziwym pedagogicznym komandosemwszechstronnym i nieustannie aktywnym w ratowaniu życia swojego podopiecznego ${ }^{14}$. Bądź też przyjąć postawę „,pedagoga jutra" ${ }^{\prime 15}$ posiadającego szereg umiejętności społecznych takich, jak:

- dokonywanie wyborów i podejmowanie trafnych decyzji w sytuacjach kryzysowych;

- $\quad$ prowadzenie efektywnej wielopoziomowej komunikacji umożliwiającej wymianę informacji lub usług z jednostkami o specyficznych właściwościach demograficzno-społecznych, jak osoby młode, niewykształcone, chore bądź obciążone szeroko pojętymi dysfunkcjami społecznymi (jak uzależnienia, demoralizacja); ubogie lub majętne; pełniące prestiżowe funkcje decydentami oraz przedstawicielami instytucji;

- $\quad$ nawiązywanie i podtrzymywanie stosunków współpracy międzysektorowej, jako istotnej kompetencji sprzyjającej formułowaniu zindywidualizowanej oferty pomocy społecznej, koncentrującej wyselekcjonowane z bogatego spektrum dostępnych na rynku usługi. Umiejętność koordynacji działań pomiędzy wieloma usługodawcami wiąże się również z umiejętnościami zarządzania zasobami ludzkimi, organizacyjnymi i materialnymi. Ponadto wymaga zbudowania wspólnej wizji programu oddziaływań opartych o tożsame rozumienie definicji, zbieżność celów i wartości; uzgodnienia roli partycypantów, ich zadań i zakresu odpowiedzialności; budowania i ciąłego motywowania do optymistycznej wizji współpracy, wiary w osiągnięcie sukcesu, poszanowania dla doświadczeń czy wniesionego we wspólną aktywność wkładu, wzajemnego rozpoznawania sił, pełnego wykorzystywania potencjałów, konstruktywnej informacji zwrotnej, sztuki rozwiązywania konfliktów oraz stałej gotowości do podejmowania trudu wdrażania modyfikacji na rzecz progresu. Te wszystkie procesy wyszczególnione przez J. Goldmana i M. Salusa winny zapewnić sukces pracy, jeśli zostaną odpowiednio wdrożone i koordynowane przez jednostkę o umiejętnościach managerskich ${ }^{16}$;

- doświadczenie życiowe, bogaty warsztat metodyczny oraz naukową wiedzę o mechanizmach i procesach społecznych. Wyróżnione zasoby pozwalają dokonywać trafnej

13 A. Węgliński, Etos i misja zawodowa sądowych kuratorów rodzinnych, „Opieka Wychowanie Terapia " 2006, nr 3-4 (67-68), s. 30-32.

14 A. Szecówka, Kształtowanie „komandosa pedagogicznego" dla potrzeb resocjalizacji, [w:] J. Pańczyk (red.), Forum Pedagogów specjalnych XXI wieku, Łódź 2004.

15 A. Karłyk - Ćwik, Rola, typy i zadania pedagogów resocjalizacyjnych a samoocena poziomu ich kompetencji zawodowych, „Opieka Wychowanie Terapia” 2008, nr 1-2 (73-74), s. 78.

16 M. Gawęcka, Niedostrzeżone obszary pracy kuratora rodzinnego w ujęciu probacji zorientowanej na rodzinie obciażonej zarządzeniami sądu rodzinnego, „Probacja” 2011, nr 1, s. 63. Por.: E. Jarosz, Idee multisektorowości w rozwiązywaniu problemów przemocy i zaniedbania dziecka w rodzinie- znaczenie dla pracy socjalnej [w:] E. Marynowicz-Hetka, M. Granosik, D. Wolska-Bylińska (red.), Badania w pracy socjalnej/społecznej-przegladd dokonań i perspektyw, Łódź 2007. 
diagnozy stanu wyjściowego, podejmować właściwe decyzje determinujące przyszłe losy podopiecznych oraz przeprowadzić obserwacje i analizy rzeczywistości niezależnie od osobistych przekonań;

- szeroki wachlarz kompetencji interpersonalnych jak empatia (świadomość własnych stanów emocjonalnych, odczytywanie i rozumienie innych); opanowanie mowy niewerbalnej własnego ciała; umiejętność budowania atmosfery zaufania i bezpieczeństwa; ogłada, obycie i kultura osobista; poszanowanie godności ludzkiej oraz tolerancja przy zachowaniu postawy asertywności i braku akceptacji dla szkodliwej społecznie dewiacji; odwagę, nieustępliwość i „przebojowość”; ; refleksyjność w myśleniu i działaniu wspartą energią i kreatywnością; otwartość i autentyczność w kontakcie z klientem; maksymalnie osiagalny obiektywizm; kierowanie się rzetelnymi informacjami czy stosowanie właściwej argumentacji w poradnictwie; jak również innych umiejętności swoistych dla reprezentanta zawodu zaufania społecznego ${ }^{17}$.

Dla zwiększenia efektywności pracy resocjalizacyjnej, kurator rodzinny powinien przyjąć tzw. nowy paradygmat $\mathrm{w}$ wychowaniu młodzieży niedostosowanej społecznie. Opiera się on głównie na prewencji zagrożeń patologia, profilaktyce oraz reedukacji poprzez przełamywanie kryzysów wartości czy osobistego poczucia anomii ${ }^{18}$. Nowy paradygmat teoretycznie opiera się o założenia prężnie rozwijającej się idei promocji zdrowia w ujęciu salutogenetycznym ${ }^{19}$ stawiającej na pomnażanie potencjału osobistego człowieka, budzeniu uśpionych i nieuświadomionych zasobów oraz energii niezbędnej do dokonywania zmian w kierunku szeroko pojętego zdrowia: duchowego, fizycznego, psychicznego, społecznego, seksualnego, itd. ${ }^{20}$.

Kurator rodzinny w codziennej pracy winien stronić od niekonstruktywnych postaw wychowawczych takich, jak: nadmiernej koncentracji na zadaniach korygująco-nauczających (instruktor, korektor) czy skrajnym oddaniu się relacjom partnerskim (destruktywne emocjonalne i behawioralne uzależnianie od siebie podopiecznego, przekraczanie granic prywatności, zacieranie roli przedstawiciela wymiaru sprawiedliwości na rzecz towarzyszenia opartego na "toksycznej" i ograniczającej miłości). Kurator nie może sytuować się na skrajnych pozycjach kontinuum zadaniowości i emocjonalności ${ }^{21}$. Ta umiejętność wymaga rozumnego zarządzania procesem wychowawczym, w którym zachować należy roztropność i równowagę pomiędzy rządzeniem (ti. dochodzeniem do celu), rozkazywaniem (czyli wskazywaniem tego, co oczekiwane i niepożądane w określonych warunkach) oraz wzmacnianiem ${ }^{22}$ (czyli świadomym organizowaniem sytuacji

17 A. W. Nocuń, J. Szmagalski, Podstawowe umiejętności w pracy socjalnej i ich kształcenie, Katowice 1998, s. 23-27; A. Olech, Etos zawodowy pracowników socjalnych. Wartości, normy, dylematy etyczne, Katowice 2006, s. 109114; R. K. James, B. E. Gilliland, Strategie interwencji kryzysowej, Warszawa 2008, s. 44-46; por.: W. Mikołajewicz, Praca Socjalna jako działanie wychowawcze, Katowice 1999.

18 A. Jaworska, O nowym paradygmacie w wychowaniu młodziė̇y niedostosowanej społecznie, „Opieka Wychowanie Terapia" 2008, nr 3-4 (75-76), s. 35-39.

19 A. Antonovsky, Rozwikłanie tajemnicy zdrowia. Jak radzić sobie ze stresem i nie zachorować, Warszawa 2005, s. 19-25; G. Dolińska-Zygmunt, Orientacja salutogenetyczna w problematyce zdrowotnej. Model Antonovsky'ego, [w:] tejże (red.), Podstawy psychologii zdrowia, Wrocław 2001.

20 Por:: B. Woynaroska, Edukacja zdrowotna-podstawy teoretyczne i metodyczne, Warszawa 2010, s. 30-32.

${ }^{21}$ Role i typy pedagogów resocjalizacyjnych, do grona których niepodważalnie zaliczamy kuratora opisuje A. Karłyk-Ćwik, dz. cyt., s. 39-44.

22 W oryginale: karaniem rozumianym jako wskazywanie nieprawidłowych płaszczyzn aktywności wychowanka, wyszczególnieniem zawinionej działalności z nastawieniem na oddziaływanie awersyjne. Choć autor zakłada możliwość naprawienia szkód- osobiście skłaniam się ku progresywnej (prorozwojowej) formie dysponowania szerokim wachlarzem bodźców z przewagą wzmocnień pozytywnych. 
wychowawczych lub dysponowaniem bodźcami w celu wywołania określonej reakcji) ${ }^{23}$. Takie rozwiązanie, szczególnie w kontekście dominującej tematyki pracy, czyli rozwijania aspiracji życiowych podopiecznego, umożliwia przyjęcie fenomenologicznej orientacji (podejścia) skoncentrowanej na osobie. C. Roger wiąże je z rozwijaniem indywidualnych możliwości służących podtrzymaniu i wzmacnianiu własnego organizmu (cele zbieżne z ideą salutogenezy), „,instynktem samodoskonalenia", samorealizacją czy tendencją (samo-) aktualizującą człowieka ${ }^{24}$. Operacjonalizacja powyższych założeń wymaga zastosowania odpowiednich metod pracy, takich jak:

- antropotechnik będących manipulacjami w obrębie interakcji wychowawczych (tj. metoda wptywu osobistego oparta na wewnętrznym kontakcie wychowawczym i autorytecie; przykład własny umożliwiający w warunkach dodatkowego wzmocnienia rówieśniczego, naśladowanie zachowań, przejmowania postaw i poglądów wychowawcy lub podawanych wzorów osobowych; doradzanie wychowazwcze w kwestiach istotnych dla podopiecznego i na jego wyraźną prośbę czy przekonywanie w oparciu o logiczną i jasną argumentację) $)^{25}$. Tego typu techniki znajdują swoje odzwierciedlenie m.in. w terapii otoczeniem (milieu therapy) A. Aichhorna ${ }^{26}$, praktyce R. Makowskiego ${ }^{27}$ czy działalności wychowawczo--opiekuńczej i terapeutycznej A. Szecówki.

- Oddziaływanie sytuacyjne, czyli manipulowanie sytuacjami wychowawczymi: modyfikowanie aktualnych, w celu uzyskania ich zbieżności z oczekiwaniami wychowawcy; podtrzymywanie interakcji, które zapewniają dostęp do konstruktywnych bodźców/ wprowadzają czynniki neutralizujące zaburzenia; organizowanie nowych w zależności od bieżących potrzeb. Do metod w tej kategorii zaliczamy: organizacje sytuacji uczacych, których naturalne następstwa stają się źródłem wzmocnień, niezależnie od interwencji opiekuna oraz intencjonalne dystrybuowanie kar i nagród w celu wywołania określonych reakcji; uświadamianie skutków zachowań poprzez odwoływanie się do wiedzy i doświadczeń wychowanka oraz zachęcanie do dokonywanie rachunku zysku i strat; a także treningi będące wielokrotnym powtarzaniem aktywności w określonych warunkach i wariantach, prowadzacce do wykształcenia oczekiwanych nawyków ${ }^{28}$. Zarówno stosowanie metod wpływu własnego, jak i organizacji sytuacji wychowawczych, wymaga wcześniejszej diagnozy oraz umiaru w inicjowaniu interwencji. Z. Zgud, w trosce o ochronę prawa do wolności, samostanowienia oraz samorealizacji, jasno określa wymiar pozytywny i negatywny zasady subsydiarności w pomocy drugiemu człowiekowi ${ }^{29}$. Uwzględnienie jego porad jest tym bardziej istotne w procesie kształtowania aspiracji podopiecznego.

Istnieje szeroki wachlarz metod pracy resocjalizacyjnej i reedukacyjnej jaki stanowić powinien warsztat pracy kuratora sądowego. Na szczególną uwagę zasługują takie działania jak organizacja kuratorskich świetlic socjoterapeutycznych, w których z ramienia organizacji zapewnia się holistycz-

${ }^{23}$ Szerokie studium problemu wraz z wyszczególnieniem następstw nadmiaru poszczególnych komponentów oraz praktycznych wskazówek dla wychowawców zawiera opracowanie: J. Woronieckiego, Umiejętność rządzenia i rozkazywania, Wrocław 1992.

24 Por.: A. Fidelus, Podejście skoncentrowane na osobie w procesie probacji, „Probacja” 2010, nr 1, s. 70-73.

25 S. Górski, Metodyka resocjalizacji, Warszawa 1985, s. 142-158.

26 Por.: P. Kazimierz, Psychopatia, Warszawa 2000, s. 119.

27 Por.: R. Makowski, Za murami poprawczaka, Warszawa 2009.

28 S. Górski, dz. cyt., s. 160-171.

29 Autor zakłada interweniowanie tylko i wyłącznie w sytuacji, gdy jednostka nie jest w stanie samodzielnie poradzić sobie z pokonaniem trudności, nie posiada ku temu odpowiednich zasobów. Por.: Z. Zgryd, Zasada subsydiarności w prawie europejskim, Zakamycze 1999. 
ne oddziaływania wykraczające poza możliwości samego kuratora. W takich placówkach umożliwia się kontakt z rówieśnikami (czego walorem jest między innymi: samoistna grupa wsparcia, edukacja rówieśnicza, wymiana doświadczeń) ${ }^{30}$; terapię poprzez zabawę, sport, sztukę rozwijanie zainteresowań czy zyskiwanie doświadczeń w oparciu o resocjalizację przez pracę ${ }^{31}$, jak również zaspakajanie podstawowych potrzeb egzystencjalnych (psychohigienicznych, sanitarnych itd.), które wielokrotnie zaniedbywane są $\mathrm{w}$ rodzinach dysfunkcyjnych objętych nadzorem sądu rodzinnego ${ }^{32}$. Taka zinstytucjonalizowana pomoc $w$ otwartym środowisku jest po części realizacją idei holistycznego oraz systemowego ujęcia wsparcia. W podobnym nurcie utrzymana jest nowatorska forma służby kuratorskiej autorstwa wrocławskiej praktyk V. Będkowskiej-Heine, rodzinna konsultacja resocjalizacyjna-szybkie dorastanie. Metoda wyrosła na bazie niedyrektywnego poradnictwa, terapii rodzinnej i edukacji obejmującej pogłębianie wiedzy oraz umiejętności wychowawczych. Jej warunkiem jest dobrowolne uczestnictwo i pełne zaangażowanie wszystkich członków rodziny, a celem wyznaczenie w sposób kolektywny (wynegocjowanie) wspólnej definicji „„dojrzałego życia", którą każdy członek rodziny stara się wdrażać we własne życie. Konsultacja realizowana jest w wymiarze 6-12 spotkań (łącznie 12-24 godziny- minimalnie jedno spotkanie miesięcznie), w ramach których kolejno dokonuje się 1) konfrontacji z sytuacją problemowa, 2) szacuje się poziom ryzyka i szans resocjalizacyjnych, 3) tworzenie rodzinnej definicji „,dorosłego życia”, 4) ustalanie podstaw rodzinnego podejmowania decyzji, 5) zaplanowanie naprawy szkód będących następstwem dysfunkcji rodziny/demoralizacji nieletniego, 6) kreowanie planu naprawy szkód na przyszłość wraz z określeniem czasu realizacji programu ${ }^{33}$. Rodzinna konsultacja jest jednym $\mathrm{z}$ bardziej efektywnych narzędzi zapewniających wzrost aspiracji życiowych jej członków. Braki $\mathrm{w}$ wiedzy oraz nieadekwatne do warunków funkcjonowania umiejętności zostają uzupełnione i zmodyfikowane w odpowiednim kierunku sprzyjającym osobistemu rozwojowi. Dodatkowo w ramach oddziaływań uczestnicy przechodzą intensywny trening umiejętności społecznych stając się bardziej samodzielnymi i zdolnymi do organizacji własnego oraz rodzinnego środowiska życia. Całość oddziaływań reedukacyjnych często bazuje na wspólnie opracowanym dokumencie mającym na celu regulować warunki współpracy.

Częstokroć w praktyce kuratorskiej służby sądowej dokonuje się podpisania dokumentu regulującego przebieg nadzoru. Kontrakt zawiązywany pomiędzy przedstawicielem wymiaru sprawiedliwości, a nieletnim obejmuje realizację pojedynczych, jasno określonych zadań jak: skrupulatne wywiązywanie się z obowiązku szkolnego, zwiększenie frekwencji na zajęciach, pracach domowych czy znalezienie zatrudnienia. Dobór treści kontraktu uzależniony jest od indywidualnego przypadku (potrzeb, możliwości, dysfunkcji podopiecznego i obciążeń orzeczonych przez sąd rodzinny) - formuła choć negocjowana z małoletnim ostatecznie pozostaje w gestii kuratora. Choć w praktyce zdarzają się problemy niedające się rozwiązać (zbyt rozległe,

30 Według M. Łopakowej, jest to wdrażanie metody izolującej i upodmiotowującej. M. Łopatkowa, Jak pracować z dzieckiem i rodzina zagrożona, Warszawa 1976, s. 52.

31 Według M. Łopakowej, jest to realizacja metody kształtującej zainteresowania, rozwijającej ambicję i godność oraz zaspokajającej zapotrzebowanie na przygodę. M. Łopatkowa, dz. cyt., s. 106 i następne.

32 W Polsce funkcjonuje wiele kuratorskich świetlic socjoterapeutycznych, na terenie Poznania najprężniej działającą zdaje się być placówka „Pod serduszkiem” prowadzona przez kierownika III Zespołu Kuratorskiej Służby Sądowniczej Grunwald - Lidii Olejniczak. W opracowaniu (L. Olejniczak, Ośrodek kuratorski jako instytucja profilaktyki agresji, kurator.webd.pl/pliki/pliki/osrodki_poznan.doc, 20.11.2011) znajduje się sprawozdanie z dotychczasowej działalności. Por.: L. Pytka, dz. cyt., s. 283-284.

33 V. Będkowska-Heine, Konsultacja rodzinna jako środek stymulujący resocjalizację [w:] A. Szecówka, B. Koukola, P. Kwiatkowski (red.), Teoria i praktyka resocjalizacyjna wobec wspótczesnych zachowań dewiacyjnych w Polsce i Republice Czeskiej, Wrocław 2009, s. 119-122. 
odległe czasowo lub pozbawione wymiernego charakteru) lub występujące w formie „negatywnej" (ogólnie zakładające powstrzymywanie się od określonej aktywności), to spełniają swoje zadanie. Z badań przeprowadzonych przez Z. Ostrihanską oraz A. Greczuszkin ${ }^{34}$ wynika, iż zastosowanie kontraktów wpływa motywująco na podopiecznego. Autorki wskazują również na kształtowanie się proaktywnej postawy wobec trudności życiowych, jako podwaliny konstruktywnej samooceny i wzrostu aspiracji życiowych ${ }^{35}$. Pomimo wyszczególnionych profitów, na podstawie aktualnej wiedzy oraz doświadczeń praktyków, odnotowuje się generowanie wielu sporów dotyczących narzędzia ${ }^{36}$. Ich źródeł upatrywać można m.in. w ewaluacji, która podkreśla brak jednoznacznej korelacji z wysoką - sięgającą blisko 60\%, skutecznością procesu resocjalizacji (w grupie kontrolnej uzyskano rezultat o procentowo zbliżonym poziomie). Diagnostycznie istotne zmiany zanotowano jednak w postawie kuratora i jego stosunku do wykonywanej służby. Wygenerowane modyfikacje ukierunkowane zostały na korzyść działań wychowawczych $^{37}$. Jest to argument opowiadający się za stosowaniem kontraktów oraz kontynuacji badań w kierunku poprawy ich skuteczności.

Przytoczone przykłady łączy wspólny element osoby kuratora jako kluczowego „narzędzia" zmiany podopiecznego. To od jego osobistego poczucia misji społecznej (zawodowej) oraz kompetencji zależy efekt oddziaływań, czyli wzrost aspiracji podopiecznego. Teza ta bynajmniej zbieżna jest z doktryną pedagogiczną „lepienia z gliny" ${ }^{\prime \prime 3}$, nie podważa również podmiotowości małoletniego, lecz podkreśla korelacje jego postawy (a w szczególności inicjatywy działania) od aktywności obdarzonego zaufaniem i autorytetem dorosłego. W tym celu kurator winien stać się mentorem, przeewodnikiem moralnym oraz coachem. Ta nowa forma wsparcia psychologicznego umożliwia dynamiczny rozwój osobowości jednostki pod warunkiem wykazywania przez nią pewnej chęci zmiany czy potrzeby bycia lepszym. Coaching staje się zatem idealnym połączeniem wcześniejszych praktyk. Jest odblokowywaniem potencjału w celu maksymalizacji dokonań (wzrostu aspiracji), który na drodze indywidualnego kontaktu, dialogu, doświadczania i holistycznego ujęcia (coaching holistyczny) staje się przyczyną prawidłowej adaptacji oraz „Wzrostu” podopiecznego (life coaching) ${ }^{39}$.

Choć wprowadzanie szeregu nowych określeń dla pełnionych przez kuratora funkcji jako pracownika społecznego jest swego rodzaju potęgowaniem utopijności idei resocjalizacji oraz namnażaniem zbędnej warstwy teoretycznej dalekiej od praktyki, to wnikliwa analiza niniejszej nomenklatury pozwala dokonać wizualizacji warstwy aksjologicznej, której fundamentalną wartość stanowi nieprzypadkowe i funkcjonalne spotkanie dwóch osób. Częstokroć jesteśmy świadkami pięknych biografii klientów, $\mathrm{w}$ których zachodzą diametralne zmiany postaw, hierarchii wartości czy poprawy warunków życia (czyli resocjalizacja). Spotkanie przez nich odpowiedniej osoby w odpowiednim miejscu i czasie, być może w momencie największego życiowego załamania - w sytuacji kryzysowej, staje się swoistym punktem zwrotnym, rzutującym na dalsze losy czło-

${ }^{34}$ Z. Ostrihanska, A. Greczuszkin, Praca z indywidualnym przypadkiem w nadzorze rodzinnego kuratora sadowego, Lublin 2005.

35 Dotyczy bowiem problemów, które zostały wskazane przez podopiecznego jako istotne.

${ }_{36}$ M.in. dotyczące sankcji lub gratyfikacji za realizację postanowień kontraktu czy zasadność podpisywania umowy przez nieletniego nieposiadającego pełni zdolności do czynności prawnych. Z. Ostrihanska, A. Greczuszkin,dz. cyt., s. 218-224, 240-241.

${ }_{37}$ Szczegółowe wyniki badań, zobrazowane w postaci tabeli, dostępne są w przytaczanym opracowaniu. Tamże, s. 234.

${ }_{38}$ Por.: H.R.Schaffer, Wzajemność kontroli we wczesnym dzieciństwie [w:] A.Brzezińska, G.Lutomski (red.), Dziecko w świecie ludzi i przedmiotów, Poznań 1994, s.125-149.

${ }_{39}$ A.Kieszkowska, Coaching jako forma wspomagania rozwoju w procesie integracji społecznej, „Probacja” 2010, nr 2, s.87-94. 
wieka. Zatem jeśli istnieje możliwość kontaktowania ze sobą potrzebujących (tj. dzieci i nastolatków pozostającym w okresie sensytywnym, które nie usztywniły się jeszcze w dewiacyjnych schematach) z doradcami, pośrednikami, terapeutami, mobilizatorami, enablerami, providerami, nauczycielami, przewodnikami, ekspertami, poszukiwaczami, inicjatorami, powiernikami, adwersarzami, aktywistami, organizatorami i informatorami, a kontakt ten przyczynić się może do zmian na poziomie jednostkowym, rodzinnym czy społecznym to być może warto zainwestować odpowiednie zasoby w celu rewizji społecznej opinii publicznej na temat skuteczności resocjalizacji. Ta uzależniona jest od świadomości spotkania z równorzędnym Człowiekiem.

\section{Bibliografia}

Antonovsky A., Rozwiktanie tajemnicy zdrowia. Jak radzić sobie ze stresem i nie zachorować, Warszawa 2005.

Będkowska-Heine V., Konsultacja rodzinna jako środek stymulujący resocjalizację [w:] Szecówka A., Koukola B., Kwiatkowski P.(red.), Teoria i praktyka resocjalizacyjna wobec wspótczesnych zachowań dewiacyjnych w Polsce i Republice Czeskiej, Wrocław 2009.

Brzezińska A., Psychologia rozwoju człowieka, [w:] Strelau J. (red.), Psychologia, t. 1, Gdańsk 2000.

Długosz P., Aspiracje życiowe młodzieży pogranicza, Kraków 2010.

Dolińska-Zygmunt G., Orientacja salutogenetyczna w problematyce zdrowotnej. Model Antonovsky'ego, [w:] tejże (red.), Podstawy psychologii zdrowia, Wrocław 2001.

Fidelus A., Podejście skoncentrowane na osobę w procesie probacji, „Probacja” 2010, nr 1.

Gawęcka M., Niedostrzeżone obszary pracy kuratora rodzinnego w ujęciu probacji zorientowanej na rodzinie obciażonej zarządzeniami sądu rodzinnego, „Probacja” 2011, nr 1.

Górski S., Metodyka resocjalizacji, Warszawa 1985.

James R. K, Gilliland B. E., Strategie interwencji kryzysowej, Warszawa 2008.

Jarosz E., Idee multisektorowości w rozwiazywaniu problemów przemocy i zaniedbania dziecka w rodzinie-znaczenie dla pracy socjalnej [w:] Marynowicz-Hetka E., Granosik M., Wolska-Bylińska D. (red.), Badania w pracy socjalnej/społecznej- przegląd dokonań i perspektyw, Łódź 2007.

Jaworska A., O nowym paradygmacie w wychowaniu młodzieży niedostosowanej społecznie, „Opieka Wychowanie Terapia” 2008, nr 3-4 (75-76).

Karłyk-Ćwik A., Rola, typy izadania pedagogów resocjalizacyjnych w samoocena poziomu ich kompetencji zawodowych, "Opieka Wychowanie Terapia" 2008, nr 1-2 (73-74).

Kazimierz P., Psychopatia, Warszawa 2000.

Kieszkowska A., Coaching jako forma wspomagania rozwoju w procesie integracji społecznej, „Probacja” 2010, nr 2.

Łopatkowa M., Jak pracować z dzieckiem i rodzina zagrożona, Warszawa 1976.

Makowski R., Za murami poprawczaka, Warszawa 2009.

Matlakiewicz A., Solarczyk-Szwec H., Dorośli uczą się inaczej, Torun 2009.

Mikołajewicz W., Praca Socjalna Jako działanie wychowawcze, Katowice 1999.

Nocuń A. W, Szmagalski J., Podstawowe umiejętności w pracy socjalnej i ich kształcenie, Katowice 1998.

Olech A., Etos zawodowy pracowników socjalnych. Wartości, normy, dylematy etyczne, Katowice 2006.

Ostrihanska Z., Greczuszkin A., Praca z indywidualnym przypadkiem w nadzorze rodzinnego kuratora sądowego, Norberinum, Lublin 2005.

Petraitis J., Flay B. R., Miller T. Q , Reviewing Theories of Adolescent Substance Use: Organizing Pieces in the Puzzle, „Psychological Bulletin" 1995, vol. 117 (1).

Pytka L., Pedagogika resocjalizacyjna. Wybrane zagadnienia teoretyczne, diagnostyczne i metodyczne, Warszawa 2008.

Schaffer H. R., Wzajemność kontroli we wczesnym dzieciństwie [w:] Brzezińska A., Lutomski G. (red.), Dziecko w śziecie ludzi i przedmiotów, Poznań 1994.

Straś-Romanowska M., Późna dorosłość. Wiek starzenia się, [w:] Harwas-Napierała B., Trempała J. (red.), Psychologia rozzoju człowieka. Charakterystyka okresów życia, t. 2, Warszawa 2007.

Szecówka A., Kształtowanie „komandosa pedagogicznego" dla potrzeb resocjalizacji, [w:] Pańczyk J. (red.), Forum Pedagogów specjalnych XXI wieku, Łódź 2004.

Węgliński A., Etos i misja zawodowa sądowych kuratorów rodzinnych, „Opieka Wychowanie Terapia” 2006, nr 3-4 (67-68).

Woroniecki J., Umiejętność rządzenia i rozkazywania, Wrocław 1992.

Woynaroska B., Edukacja zdrowotna-podstawy teoretyczne i metodyczne, Warszawa 2010.

Wysocka E., Diagnoza w resocjalizacji, Warszawa 2008.

Zgryd Z., Zasada subsydiarności w prawie europejskim, Zakamycze 1999. 


\footnotetext{
Akty prawne

Kodeks Rodzinny i Opiekuńczy z dn. 25 lutego $1964 r$.

Ustawa z dn. 26 października1982 r. o postępowaniu w sprawach nieletnich.

Ustawa $z$ dn. 27 lipca 2011o kuratorach sadowych.
}

\section{Netografia}

Olejniczak L., Ośrodek kuratorski jako instytucja profilaktyki agresji, kurator.webd.pl/pliki/pliki/osrodki_poznan.doc, 20.11.2011.

\section{STRESZCZENIE}

Treść artykułu zawiera analizę teoretyczną roli kuratora rodzinnego w kształtowaniu się hierarchii wartości oraz postaw wobec przyszłości, składających się na szeroko pojęte aspiracje życiowe podopiecznego. Biorąc pod uwagę specyfikę oraz indywidualne i społeczne źródła dążeń nieletniego, autor szczególną funkcję przypisuje interwencji wychowawczej kuratora, który to, odchodząc od modelu nadzoru kontrolno-dyscyplinującego, winien stać się mentorem, coachem i towarzyszem $\mathrm{w}$ procesie kompensowania posiadanych deficytów oraz prawidłowego rozwoju. Ten ostatni, zakłada pomnażanie zasobów, w celu realizacji pozytywnej wizji przyszłości oraz bieżącej aktywności zgodnej z powszechnie obowiązującymi normami jako środkami dochodzenia do niej. Autorka ponadto wyszczególnia najskuteczniejsze metody sprzyjające realizacji niniejszego celu.

Słowa kluczowe: aspiracje życiowe, metody prowadzenia nadzoru kuratorskiego nad nieletnim, coaching, specyfika relacji kuratora z podopiecznym.

\section{The Role of a Judicial Educator in the Process of Shaping Life Aspirations to be Achieved by}

\section{Summary}

The article shows particular role of juridical familiar educator in charge's life pretensions creative process. His major influence on value hierarchy and own future attitude is depended of his style of work, which is getting changed from disciplinary to human oriented model. Moreover, author enlists various methods to equalizing charge's deficits and helping with self-development up to his normal level, as a very important goal of juridical familiar educator intervention. The way to gain it, has been situated in increasing human own resources and aiming positive future prospect of live through proper pretension.

Key words: life pretensions, juridical familiar educator's methods of work, coaching method, features of scrutiny relationship 